Gut, 1987, 28, 1077-1083

\title{
Propionate absorption and metabolism in the rabbit hindgut
}

\author{
M Y VERNAY \\ From the Institute of Physiology, Toulouse, France
}

SUMmary Propionate disappearance from the loops of the hindgut in the rabbit was evaluated by measuring variations in the concentration of propionate in caecocolonic loops and differences in the arterial and venous plasma. In vivo metabolism in gut and liver tissues was studied after introduction of $\left(1-{ }^{14} \mathrm{C}\right)$ propionate into the caecocolonic loops. The rate of disappearance from the loops was always quantitatively significant but was greater in the proximal colon. Hindgut tissue metabolised propionate and the intensity of the metabolism varied with the segment studied; the proximal colon showed by far the highest propionate consumption. Radioactivity was found in a certain number of free amino acids, organic acids, sugars, lipid soluble substances and proteins. Propionate is an efficient respiratory fuel for the colonocyte and a good precursor for gluconeogenesis.

It is well known that volatile fatty acids (VFA) - for example, acetate, propionate and butyrate - are the major end products of microbial fermentation in the digestive tract of polygastric and monogastric animals. ${ }^{2}$ In the rabbit a large proportion of its energy requirement $(30-40 \%)$ is derived from the catabolism of the bacterial metabolites formed in the hindgut $;^{2-5}$ nearly half of the energy supplied is because of the butyrate. "The large intestine tissues metabolise the VFA, the intensity of this metabolism varying with the location in the gut and the excretion pattern. ${ }^{-1}$ It has been shown that butyrate ${ }^{6}$ is a good respiratory fuel for the colonocyte, and that acetate ${ }^{7}$ is mainly converted into aspartate and glutamate; these can be considered as 'stock forms' which can be diverted either towards oxidative metabolism or towards protein synthesis. For monogastric animals, much less information is available about the metabolism of propionate by caecal ${ }^{10-11}$ and colonic mucosa. Thus the aim of the present investigation is to determine the extent to which propionate is metabolised during its absorption from the large intestine of the rabbit.

Address for correspondence: Dr M Y Vernay, Institut de Physiologic, 2 rue $F$ Magendie, 31400) Toulouse, France.

Received for publication 29 January 1987.

\section{Methods}

ANIMALS

Twelve male rabbits (Oryctolagus cuniculus) with an average weight of $2.5 \mathrm{~kg}$ were provided with oats and lucerne ad libitum. All experiments were carried out during the hard faeces period of the animals. ${ }^{213}$

\section{EXPERIMENTAL PROCEDURE}

Anaesthesia was achieved by administering a pentobarbital solution, $(20 \mathrm{mg} / \mathrm{kg})$, through the marginal vein of the ear. After laparotomy the hindgut was removed and three loops of approximately equivalent parameters (wet weight, serosal area) were made from the caecum (median zone) and the proximal (aboral segment) and distal colon (for anatomical detail, see Snipes et $\mathrm{l}^{l^{14}}$ ). The sites of the loops were chosen for suitability for cannulation of the venous drainage. Polyethylene catheters (PE 90) were inserted into small caecal and colonic veins draining each loop, and care was taken to ensure that blood circulation was not damaged. A carotid was exposed and cannulated (PE 190). The loops were washed with sodium chloride $(9 \mathrm{~g} / \mathrm{l})$ at $38^{\circ} \mathrm{C}$, then the three loops were filled with $5 \mathrm{ml}$ of the experimental solution. This solution contained $(\mathrm{mM}): 159 \mathrm{Na}$, $17 \mathrm{~K}, 0.7 \mathrm{Ca}, 4.3 \mathrm{Mg}, 83 \mathrm{Cl}, 26 \mathrm{HCO}_{3}, 19 \mathrm{PO}_{4}, 37$ acetate, 10 propionate, 15 butyrate, had a $\mathrm{pH}$ of $7 \cdot 1$ 
at $38^{\circ} \mathrm{C}$ and an osmolality of $330 \mathrm{mosmol} / \mathrm{kg}$. A nonabsorbable marker substance, $2 \mathrm{~g}$ polyethylene glycol// (PEG) was added to the control solution. For each of the four metabolism studies, $30 \mu \mathrm{Ci}\left(1-{ }^{14} \mathrm{C}\right)$ propionate was added to the test solution. Blood samples $(1 \mathrm{ml})$ were simultaneously collected through the catheters before experimentation and every five minutes for 20 minutes in a heparinised beaker. After each operation the volume of blood withdrawn was replaced with a physiological saline solution and the catheter was filled with a solution of heparin $(40 \mathrm{IU} / \mathrm{ml}$ physiological saline $)$. At the end of the incubation $(20 \mathrm{~min})$ blood samples were taken from the portal and hepatic veins. The loops were then emptied and the liquids were immediately placed in ice. The intestinal loops together with a portion of each lobe of the liver were resected, blotted and weighed; the serosal area of the loops was evaluated by planimetry.

The preparation of the colonic tissues used in this study has been described previously ${ }^{4-7}$ and is briefly summarised below. The tissues were homogenised in ice cold water using an Ultra-Turrax electric blender and with the homogenates, an extraction in boiling water allowed the volatile fraction to be recovered; the insoluble fraction (proteins) being removed by centrifugation $(30 \mathrm{~min}$ at $10000 \mathrm{~g})$. After elimination of lipid soluble substances with chloroform (three extractions $v / v$ ) in a separating funnel, the aqueous fraction was recovered and concentrated in a Rotavapor (Büchi). From the aqueous fractions free amino acids, organic acids and sugars were isolated on a cationic (Dowex $50 \times 4$ ) and an anionic (Dowex $1 \times 4)$ exchange resin column. The ${ }^{14} \mathrm{C}$ incorporation into volatile, insoluble, lipid soluble and aqueous fractions was measured in a liquid scintillation counter (Packard 460 C). The propionate of the blood was determined after ethanolic extraction as described by Rémésy and Demigné, ${ }^{15}$ while propionate of the test colonic solutions was measured after acidification of $1 \mathrm{ml}$ of the sample with $100 \mu \mathrm{l}$ formic acid. The fatty acid was subsequently analysed by gas liquid chromatography (Intersmat IGC 120 DSL). Polyethylene glycol concentration was determined according to the procedure described by Hyden. ${ }^{16}$

\section{CALCULATIONS}

The formula used in calculating net propionate transport in the intestinal loops was:

\section{Net propionate transport $(\%)=$ 100-CoVo-CtVoPEGo/PEGt:CoVo}

where $V_{0}$ is the volume of fluid in the loops at the beginning of the experiment and $\mathrm{Co}$ and $\mathrm{Ct}$ are the propionate concentrations $(\mu \mathrm{mol} / \mathrm{ml})$ at the begin- ning and at the end of the experiment. ${ }^{14} \mathrm{C}$ incorporation in metabolites was expressed per $g$ wet tissue; the mean weight $(\mathrm{g})$ of caecal, proximal and distal colonic loops were respectively: $6 \cdot 3 \pm 1 \cdot 89,6 \cdot 5 \pm 1 \cdot 24$, $5 \cdot 1 \pm 1 \cdot 32$ and the corresponding mean serosal areas $\left(\mathrm{cm}^{2}\right)$ were: $27 \cdot 0 \pm 1.36,26 \cdot 0 \pm 1 \cdot 37$ and $23 \cdot 0 \pm 1 \cdot 08$.

From values for hepatic blood supply, it was assumed that for the rabbit ${ }^{17}$ the portal vein and the hepatic artery represent 90 and $10 \%$ of the afferent blood flow respectively. Thus afferent plasma concentrations are: $0 \cdot 9 \times($ portal vein $)+0 \cdot 1 \times($ aorta $)$; the percentage of propionate hepatic uptake is calculated with the ratio:

$$
\begin{gathered}
\text { (hepatic plasma) }-(\text { afferent plasma }) / \\
\text { (afferent plasma }) \times 100
\end{gathered}
$$

All the results are presented as means with their standard errors. Differences were evaluated statistically using paired or unpaired Student's $t$ test as appropriate.

\section{Results}

DISAPPEARANCE OF PROPIONATE IN INTESTINAL LOOPS

The concentration of propionate used in the present work was: $10 \cdot 8 \pm 0 \cdot 15 \mathrm{mM}$ which is regarded as physiological. ${ }^{121318}$ Twenty minutes after introduction of the test solution the rate of propionate disappearance from the intestinal loops was always high; moreover it was invariably greater in the proximal colon compared with the caecum and distal colon. At the end of incubation $40-50 \%$ of the fatty acid inserted into the loop had disappeared (Fig. 1). If the disappearance is expressed in $\mu \mathrm{mol} / \mathrm{unit}$ serosal area/20 min the corresponding net propionate flux is: $1 \cdot 2 \pm 10$ for the caecum, $1 \cdot 5 \pm 0 \cdot 16$ for the proximal colon and $1 \cdot 1 \pm 0 \cdot 04$ for the distal colon.

\section{ARTERIAL AND VENOUS PLASMA}

CONCENTRATIONS OF PROPIONATE

The mean value of propionate in arterial plasma was $11 \pm 0 \cdot 8 \mu \mathrm{mol} / 100 \mathrm{ml}$. Differences in the concentrations of propionate in the arterial and venous plasma were greater in the caecum than in the colon (Fig. 1). The concentration of the propionate in portal and hepatic plasma was $55 \pm 3.1$ and $11 \pm 1.5(\mu \mathrm{mol} / 100$ $\mathrm{ml}$ ) respectively; therefore $80 \pm 2 \cdot 4 \%$ of the absorbed propionate was removed by the liver.

\footnotetext{
${ }^{14}$ C INCORPORATION INTO BIOCHEMICAL FRACTIONS
}

Twenty minutes after introduction of $\left(1-{ }^{14} \mathrm{C}\right)$ propionate in the intestinal loops radioactivity was found to be present in caecal, colonic, and hepatic tissues (Table 1). On a per gram wet tissue basis the ${ }^{14} \mathrm{C}$ 

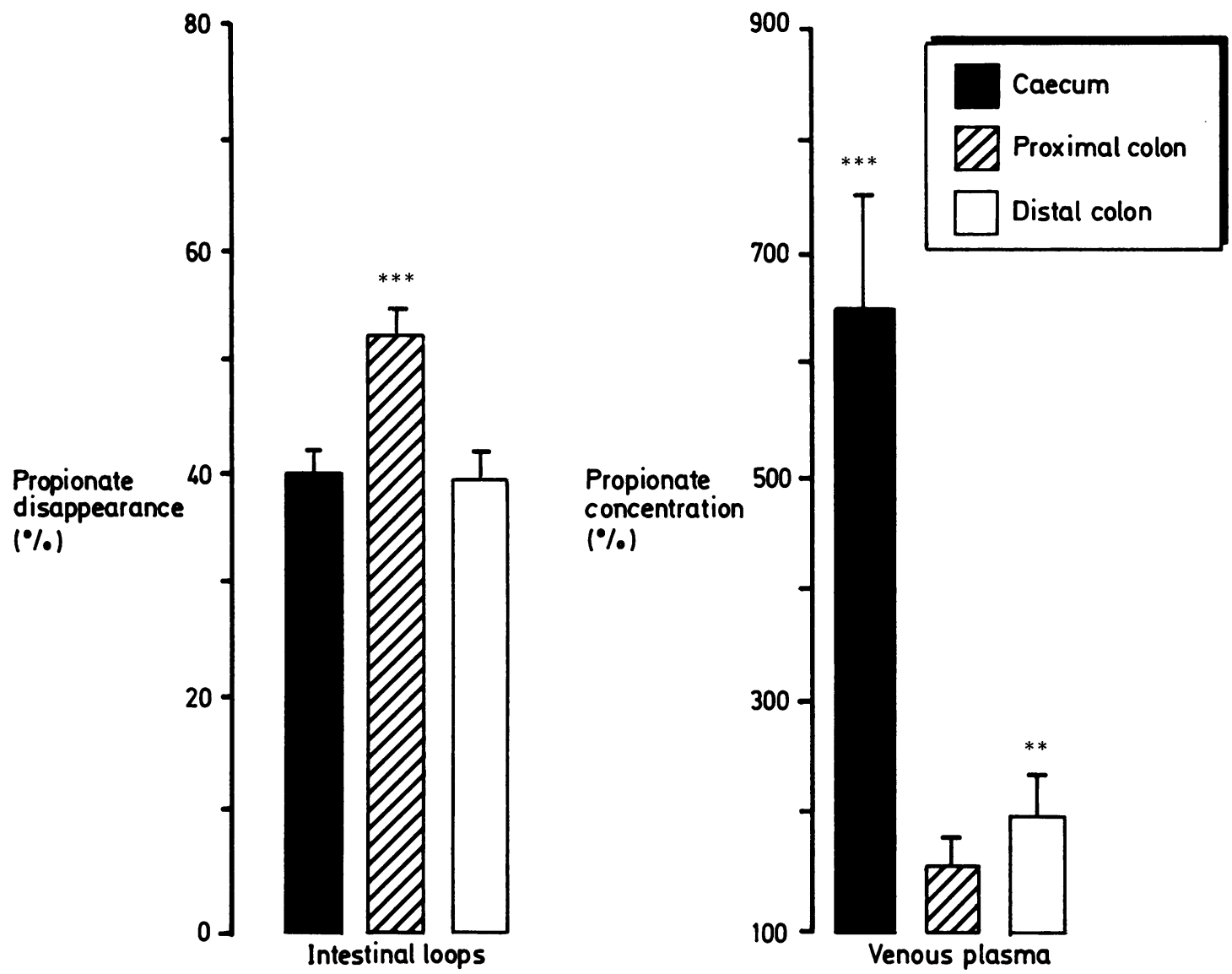

Fig. 1 Propionate disappearance from 10 caecocolonic loops is expressed as $\%$ of the initial propionate concentration in the test solution after PEG correction. Propionate concentration in venous plasma is expressed as \% of the propionate concentration in the arterial plasma. Each column with its bar represent mean $\pm S E$; propionate disappearance was significantly different at ${ }^{* *} p<0.001$ between proximal colon and caecum or distal colon; propionate concentration in the venous plasma was significantly different at: ${ }^{* * *} p<0.001$, or ${ }^{* *} p<0.01$ from propionate concentration in the arterial plasma.

content was higher in the colon than in the caecum and the liver: approximately 4-8 times more $(p<0 \cdot 001)$. It is to be noted that the amount of radioactivity recovered in the caecocolonic tissue is small compared with the quantities of ${ }^{14} \mathrm{C}$-propionate absorbed: $0 \cdot 5-0 \cdot 8 \%$ in the caecum, $1 \cdot 8-2.9 \%$ in the proximal colon and $3 \cdot 4-6 \cdot 2 \%$ in the distal colon.

The labelling balance of the biochemical fractions varied (Fig. 2). In the hindgut walls about $67 \%$ of the total radioactivity was recovered in the aqueous fraction and $16 \%$ in the insoluble fraction (proteins); radioactivity was also found in the volatile $(15 \%)$ and the lipid soluble $(2 \%)$ fractions. For the liver tissue $80 \%$ of the ${ }^{14} \mathrm{C}$ detected was incorporated in the aqueous fraction, $17 \%$ in the insoluble fraction, the remainder $(3 \%)$ was distributed on the lipid soluble and volatile fractions.
${ }^{14} \mathrm{C}$ INCORPORATION INTO METABOLITES ISOLATED FROM THE AQUEOUS FRACTION

On the autoradiographs, radiocarbon was always detected in a number of metabolites - that is, free amino acids, organic acids and sugars (Table 2; Fig. 3 ). In the gut walls the radioactivity of the aqueous fraction was mainly accounted for by organic acids $(56 \%)$, but also by amino acids $(24 \%)$ and sugars $(20 \%)$. In the case of the liver a high percentage of the radioactivity was detected in the free amino acids $(86 \%)$ and some label was recovered in sugars $(11 \%)$ and organic acids (3\%).

The details of the ${ }^{14} \mathrm{C}$ distribution into metabolites present in the aqueous fraction are reported in Table 2 . It is to be noted that in the hindgut walls the radioactivity in the free amino acids was mainly associated with glucogenic substrates - that is, 
Table 1 Incorporation of ${ }^{1+} \mathrm{C}$ into volatile, lipid-soluble, aqueous and insoluble fractions in hindgut and liver tissues 20 minutes after introduction of $\left(1-{ }^{1+} \mathrm{C}\right)$ propionate into caecocolonic loops

\begin{tabular}{|c|c|c|c|c|c|}
\hline & \multicolumn{5}{|l|}{ Fractions: } \\
\hline & Volatile & Lipidsoluble & Aqueous & Insoluble & Total \\
\hline Caecum & $7 \cdot 8 \pm 1 \cdot 24$ & $0 \cdot 8 \pm 0 \cdot 27$ & $9 \cdot 6 \pm 1 \cdot 69$ & $9 \cdot 3 \pm 2 \cdot 12$ & $27 \cdot 5 \pm 6 \cdot 32$ \\
\hline Proximal colon & $19 \cdot 1 \pm 4 \cdot 78$ & $(0 \cdot 1 \pm 0 \cdot(09$ & $93 \cdot 8 \pm 23 \cdot 45$ & 1()$\cdot 6 \pm 3 \cdot 82$ & $124 \cdot 0 \pm 31 \cdot(07$ \\
\hline Distal colon & $7 \cdot 5 \pm 2 \cdot 58$ & $0.4 \pm 0 \cdot 15$ & $225 \cdot 5 \pm 56 \cdot 38$ & $15 \cdot 1 \pm 5 \cdot 06$ & $248 \cdot 5 \pm 74.53$ \\
\hline Liver & $1 \cdot() \pm 0.32$ & $0 \cdot 1 \pm 0 \cdot(07$ & $23.3 \pm 9.45$ & $5 \cdot() \pm 2 \cdot 31$ & $29 \cdot 4 \pm 12 \cdot 18$ \\
\hline
\end{tabular}

${ }^{14} \mathrm{C}$ incorporation into the different fractions is expressed in $10^{3} \mathrm{dpm} / \mathrm{g}$ wet wt/20 $\mathrm{min}$. Each value represents the mean $\pm \mathrm{SE}$ of four samples of tissue. Differences in the variations of the ${ }^{1+} \mathrm{C}$ incorporation into the four groups were significantly different at $\mathrm{p}<0 \cdot(0) 1$ between caecal or liver and proximal or distal colon. and between proximal and distal colon.

glutamate + glutamine $(28 \%)$, methionine $(25 \%)$, alanine $(20 \%)$, aspartate + asparagine $(18 \%)$ and glycine $(8 \%)$. The labelled organic acids were mainly adipic and sebacic acids $(41 \%)$; nevertheless ${ }^{14} \mathrm{C}$ was also found in TCA cycle acids $(36 \%)$ - that is, succinate, fumarate, malate and oxaloacetate. Finally, $16 \%$ of the ${ }^{1+} \mathrm{C}$ was incorporated into lactate.

In the case of the liver tissue the highest labelling rate found in the free amino acids was mainly due to glutamate +glutamine (44\%) and to aspartate+ asparagine $(38 \%)$.

Certain of the labelled metabolites present in the gut tissues were detectable in the venous plasma. The total radioactivity measured in the aqueous fraction of the portal plasma was $3 \cdot 8 \times 10^{3} \mathrm{dpm} / \mathrm{ml}$, and $30 \%$ of the total ${ }^{14} \mathrm{C}$ was recovered in the free amino acids (alanine, aspartate and glutamate), $39 \%$ in the organic acids (succinate, malate and lactate), the remainder $(31 \%)$ in the glucose. The radioactivity found in arterial plasma ranged between $1 \cdot 1$ to $1.3 \times 10^{3} \mathrm{dpm} / \mathrm{ml}$, and the ${ }^{14} \mathrm{C}$ was only found in the lactate and glucose.

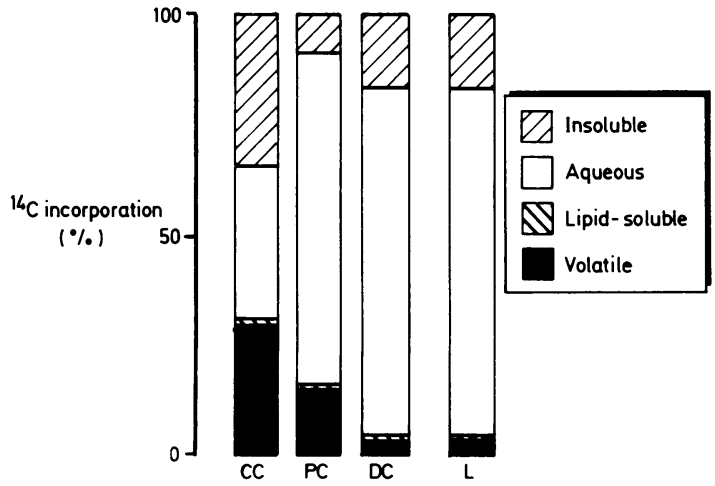

Fig. $2{ }^{14} \mathrm{C}$ incorporation into volatile, lipid soluble, aqueous and insoluble fractions in caecal $(C C)$, proximal and distal colon $(P C, D C)$ and liver $(L)$ tissues after introduction of $\left(1-{ }^{1+} C\right)$ propionate into caecocolonic loops. Values are expressed as $\%$ of the total ${ }^{1+} \mathrm{C}$ incorporation.

\section{Discussion}

This study shows that the absorption capacity of the large intestine for the propionate did not diminish with the increasing distance from the caecocolonic junction, as the variations in plasma propionate concentration might suggest. In the rabbit ${ }^{0719}$ as in ruminants, the metabolic activity of the gut epithelium explains the variations in VFA concentrations in the venous plasma. The low concentrations of this nutrient in the colonic bloodstream imply that its catabolism by the gut wall is extremely efficient, particularly in the proximal colon. In gut walls, the radioactivity found in various metabolites confirms that propionate is implicated in the metabolism of the colonocyte, but the amount of label recovered in the tissues is small compared with the quantities of ${ }^{14} \mathrm{C}$ propionate absorbed. It appears, therefore, that a large proportion is metabolised into carbon dioxide, and to a lesser extent into free amino acids, organic acids, and sugars. Some of the molecules can be stored or transported away from the gut, as most of the labelled metabolites present in gut tissues are recovered in the blood.

For polygastric animals an unknown and probably variable $(30-60 \%)$ of the absorbed propionate is oxidised or converted to other products during the absorption process through the rumen wall. ${ }^{2022}$ Evidence of extensive metabolism of propionate to lactate by the rumen epithelium has now been challenged by the results of a number of studies ${ }^{211212: 3}$ carried out with a variety of experimental techniques. But, in experiments with calves, Weigand $e t$ al $l^{2+25}$ estimated that the true conversion of this bacterial metabolite into lactate averaged less than $5 \%$, and when estimates were corrected to lactate derived directly from propionate via glucose they averaged $2 \cdot 3 \%$. Similar low estimates were found in vitro for the rumen epithelium of ewes. ${ }^{22-26}$ The nature and the distribution of the ${ }^{14} \mathrm{C}$ in the rabbit hindgut tissues show that the propionate is used by the colonocyte as a source of energy and as substrates for gluconeo- 
Table 2 Incorporation of ${ }^{1+} \mathrm{C}$ into free amino acids, organic acids and sugars of the aqueous fraction in hind gut and liver tissues 20 minutes after introduction of $\left(1-{ }^{1+} \mathrm{C}\right)$ propionate into caecocolonic loops

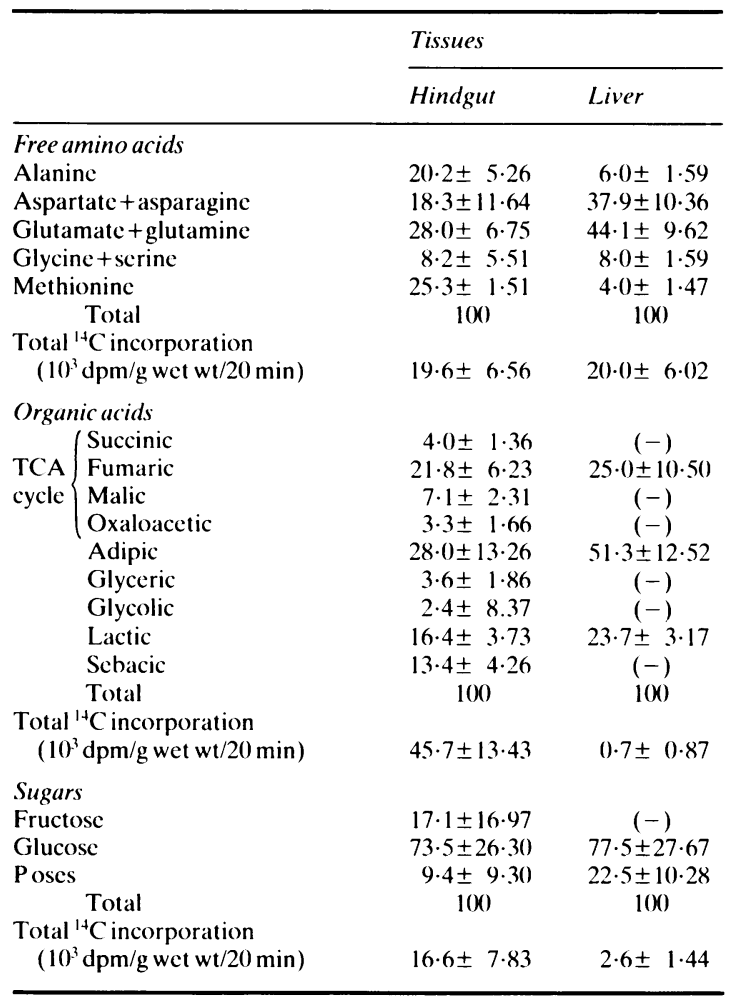

${ }^{14} \mathrm{C}$ incorporation into the different metabolites of each biochemical group is expressed as \% of the total ${ }^{14} \mathrm{C}$ incorporation in the aqueous fraction. Each value represents the mean $\pm \mathrm{SE}$ of 12 samples of gut tissues and four samples of liver tissues; ( $)$ represents nil results.

genesis, lipogenesis and protein synthesis. In the rabbit, as in the rat ${ }^{11-27}$ and the guinea-pig, ${ }^{2 \mathrm{x}}$ as well as in ruminants, ${ }^{29}$ propionate enters the metabolic pool via the methylmalonyl pathway. Indeed, the results obtained are consistent with the conversion of this fatty acid into succinate and the oxidation of succinate into oxaloacetate which is the precursor of labelled amino acids - that is, aspartate, methionine, glycine, serine and glutamate. Subsequently, the latter metabolites can be diverted towards either gluconeogenesis and/or protein synthesis. Acetate is considered to be the primary substrate for fatty acid synthesis in the ruminant ${ }^{31232}$ and the rabbit. ${ }^{33.34}$ Interestingly the present investigation suggests that propionate could also be a lipogenic precursor because a substantial labelling of free fatty acids (adipic, sebacic) and lipid soluble substances is found. This is in agreement with Prior et al,,$^{356}$ and with Whitehurst et al, ${ }^{37}$ showing that lactate and

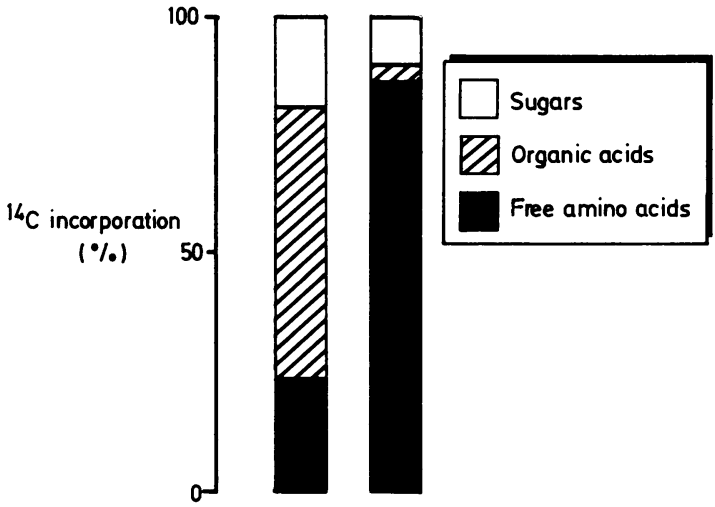

Fig. $3{ }^{14} \mathrm{C}$ incorporation into free amino acids, organic acids and sugars of the aqueous fraction in hindgut and liver tissues after introduction of $\left(1-{ }^{1+} \mathrm{C}\right)$ propionate into caecocolonic loops. Values are expressed as $\%$ of the total ${ }^{1+} \mathrm{C}$ incorporation in the aqueous fraction.

propionate are important precursors for fatty acids in vivo in the sheep and the steer fed ad libitum. Thus the existence of this metabolic pathway may explain the low portion of ${ }^{14} \mathrm{C}$ detected on glucose and lactate in the hindgut walls of the rabbit. It is to be noted that both the absorption and metabolism of propionate and butyrate, ${ }^{\circ}$ as for electrolyte handling ${ }^{1213}$ are relatively intense in the proximal colon. Indeed in an earlier work ${ }^{13}$ on the rabbit, it was shown in the large intestine, that the absorption of the VFA and cations $(\mathrm{Na}, \mathrm{K})$ is linked, likewise in the colon of the rat, ${ }^{36}$ goat, ${ }^{39}$ pig, ${ }^{11}$ sheep, ${ }^{, 1}$ and man $;{ }^{42}$ the link has been postulated to be the recycling of hydrogen ions. ${ }^{13+1+11-43}$ But the close relationship between VFA and cation absorption, as well as VFA metabolism in the rabbit, the goat, ${ }^{39}$ the equine ${ }^{43}$ and $\operatorname{man}^{44}$ also supports the hypothesis that the energy gained from colonic VFA metabolism may be used for active transfer of cations across the hindgut epithelia.

In the present experimental conditions, propionate was largely removed $(80 \%)$ from the portal blood during its passage through the liver; similar uptake values have been obtained for ruminants $s^{15+6}$ and the rat. ${ }^{47}$ The biochemical pathway through which propionate is normally launched into the TCA cycle in the liver is the same as that for the gut tissues. But the labelling of glucogenic amino acids in the former organ is greater compared with the latter, which agrees with the report of Gaitonde et al $;{ }^{27}$ for the rat, these authors have shown that ${ }^{14} \mathrm{C}$ propionate is a better source of free amino acids in the liver than in other tissues. Thus, as demonstrated by previous studies of the liver in rabbits, ${ }^{5+8}$ rats, ${ }^{+4}$ and ruminants ${ }^{51151}$ propionate is an efficient precursor of substrates for hepatic gluconeogenesis.

In arterial plasma, there is no detectable labelling 
of free amino acids suggesting that most of the molecules entering the portal circulation are taken by the hepatocyte..$^{51}$ Nevertheless very slight radioactivity was found in lactate and glucose which are directly assimilable by peripheric tissues. Surprisingly, in the rabbit the propionate not subject to liver metabolism is not metabolised by extra-hepatic tissues $^{1953}$ as is the case in ruminants..$^{54}$

In conclusion, like butyrate ${ }^{b}$ and acetate, the metabolic fate of propionate depends on the tissue which metabolises the compound. Propionate is clearly an important nutrient for the large intestine mucosa, particularly for the colonic mucosa, it is an efficient respiratory fuel for the colonocyte. In addition, it is also a good precursor for gluconeogenesis, lipogenesis and protein synthesis.

Scintillation counting and analysis of amino acids, organic acids and sugars were performed at the Centre de Physiologie Végétale LA CNRS 241-UPS. The author wishes to thank Ms Marty and $\mathrm{Mr}$ Abravanel for their invaluable help and advice in the different techniques used.

\section{References}

1 Sutton JD. The fermentation of soluble carbohydrates in rumen contents of cows fed diets containing a large proportion of hay. BrJ Nutr 1968; 22: 689-712.

2 Miller TL, Wolin MJ. Fermentations by saccharolytic intestinal bacteria. Am J Clin Nutr 1979; 32: 164-72.

3 Hoover WH, Heitmann RN. Effects of dietary fiber levels on weight gain; cecal volume and volatile fatty acids production in rabbits. $J$ Nutr $1972 ; 102$ : 245-52.

4 Parker DS. The measurement of production rates of volatile fatty acids in the caecum of the conscious rabbit. Br J Nutr 1976; 36: 61-78.

5 Marty JF, Vernay MY. Absorption and metabolism of the volatile fatty acids in the hind-gut of the rabbit. $B r J$ Nutr 1984; 51: 265-77.

6 Vernay MY, Marty JF. Absorption and metabolism of butyric acid in rabbit hind-gut. Comp Biochem Physiol 1984; 77A: 89-96.

7 Marty JF, Vernay MY, Abravanel GM. Acetate absorption and metabolism in the rabbit hindgut. Gut 1985; 26: 562-9.

8 Henning SJ, Hird FJR. Ketogenesis from butyrate and acetate by the caecum and the colon of rabbits. Biochem J 1972; 130: 785-90.

9 Henning SJ, Hird FJR. Transport of acetate and butyrate in the hind-gut of rabbits. Biochem J 1972; 130: 791-6.

10 Mottaz P, Worbe JF. Transfert des acides gras volatils dans la paroi du caecum isolé de rat. C R Soc Biol 1977; 171: $375-80$.

11 Mottaz P, Worbe JF. Synthèse de l'acide lactique par le caecum de rat au cours du transfert des acides gras volatils. Ann Biol Anim Biochim Biophys 1979; 19: 723-8.
12 Vernay MY, Marty JF, Moatti JP. Absorption of electrolytes and volatile fatty acids in the hind-gut of the rabbit. Circadian rhythm of hind-gut electrolytes and plasma aldosterone. Br J Nutr 1984; 52: 419-28.

13 Vernay MY. Absorption of inorganic ions and volatile fatty acids in the rabbit. Comp Biochem Physiol 1986; 83A: $775-84$.

14 Snipes RL, Clauss W, Weber A, Hörnicke H. Structural and functional differences in various divisions of the rabbit colon. Cell Tissue Res 1982; 225: 331-46.

15 Rémésy C, Demigné C. Determination of volatile fatty acids in plasma after ethanolic extraction. Biochem $J$ 1974; 141: 85-91.

16 Hyden S. A turbidometric method for the determination of higher polyethyleneglycols in biological materials. Lantbrukshögsk Ann 1956; 22: 139-45.

17 Neutze JM, Wyler F, Rudolf AM. Use of radioactive microspheres to assess distribution of cardiac output in rabbits. Am J Physiol 1968; 215: 486-95.

18 Leng $E$. Absorption of inorganic ions and volatile fatty acids in the rabbit caecum. BrJ Nutr 1978; 40: 509-19.

19 Vernay MY. L'absorption et le devenir des acides gras volatils digestifs chez le lapin, en relation avec la dualité de l'émission fécale. Université P. Sabatier de Toulouse: Thèse d'état, 1985.

20 Stevens CE. Fatty acid transport through the rumen epithelium. In: Phillipson AT, ed. Physiology of diges tion and metabolism in the ruminant. Newcastle-uponTyne: Oriel Press, 1970: 101-12.

21 Bergman EN. Production and utilization of metabolites by the alimentary tract as measured in portal and hepatic blood. In: McDonald IW, ed. Digestion and metabolism in the ruminant. Armidale, NSW: Univ New England Publishing Unit, 1975: 292-319.

22 Weekes TEC, Webster JF. Metabolism of propionate in the tissues of the sheep gut. Br J Nutr 1975; 33: 425-38.

23 Leng RA, Steel JW, Luick JR. Contribution of propionate to glucose synthesis in sheep. Biochem $J$ 1967; 103: 785-90.

24 Weigand E, Young JW, McGilliard AD. Extent of propionate metabolism during absorption from the bovine ruminoreticulum. Biochem J 1972; 126: 201-9.

25 Weigand E, Young JW, McGilliard AD. Extent of butyrate metabolism by bovine ruminoreticulum epithelium and the relationship to absorption rate. J Dairy Sci 1972; 55: 589-97.

26 Weekes TEC. Effects of pregnancy and lactation in sheep on the metabolism of propionate by the ruminal mucosa and on some enzymic activities in the ruminal mucosa. J Agric Sci 1972; 79: 409-21.

27 Gaitonde MK, Wharton J, Holt E. ${ }^{1+} \mathrm{C}$ labelled aminoacids and glucose in rat brain and liver after injection of $\left(2-{ }^{1+} \mathrm{C}\right)$ propionate. $J$ Neurochem 1977 ; 29 : 127-33.

28 Deaciuc IV, Botoc $M$, Soumaila SD. Lactate and pyruvate formation during gluconeogenesis from propionate in the perfused guinea-pig liver. Rev Roumaine Biochim 1979; 16: 255-60.

29 Smith RM, Osborne-White WS. Synthesis of phosphoenol-pyruvate from propionate in sheep liver. Biochem J 1971; 124: 867-76.

30 Mayfield ED, Bensadoun A, Johnson BC. Acetate metabolism in ruminant tissues. $J$ Nutr 1966; 89: 189-96. 
31 Hanson RW, Ballard FJ. The relative significance of acetate and glucose as precursors for lipid synthesis in liver and adipose tissue from ruminants. Biochem $J$ 1967; 105: 529-36.

32 Ballard FJ, Hanson RW, Kronfeld DS. Gluconeogenesis and lipogenesis in tissues from ruminant and non-ruminant animals. Fed Proc 1969; 28: 218-31.

33 Smith S. Lipogenesis in rabbit adipose tissue. $J$ Lipid Res 1975; 16: 324-31.

34 Vézinhet A, Nouguès J. Postnatal evolution of lipogenesis in adipose tissue and liver of lamb and rabbit. Ann Biol Anim Biochim Biophys 1977; 17: 851-63.

35 Prior RL. Effects of level of feed intake on lactate and acetate metabolism and lipogenesis in vivo in sheep. J Nutr 1979; 108: 926-35.

36 Prior RL, Scott RA. Effects of intravenous infusions of glucose, lactate, propionate or acetate on the induction of lipogenesis in bovine adipose tissue. J Nutr 1980; 110: 2011-9.

37 Whitehurst GB, Beitz DC, Pothoven MA, Ellison WR, Crump MH. Lactate as precursor of fatty acids in bovine adipose tissue. J Nutr 1978; 108: 1806-11.

38 Umesaki Y. Tohyama K, Mutai M. Characterization of acetate uptake by colonic epithelial cells of the rat. Pflügers Archiv 1980; 388: 205-9.

39 Argenzio RA, Miller N, Engelhardt Wv. Effect of volatile fatty acids on water and ion absorption from the goat colon. Am J Physiol 1975; 229: 977-10()2.

40 Argenzio RA, Whipp SC. Interrelationship of sodium. chloride, bicarbonate and acetate transport by the colon of the pig. J Physiol 1979; 295: 365-81.

41 Rübsamen K, Engelhardt Wv. Absorption of Na, Hions and short-chain fatty acids from the sheep colon. Pflügers Archiv 1981; 391: 141-6.

42 Ruppin H, Bar-Meir S, Soergel KH, Wood CM, Schmitt MG. Absorption of short-chain fatty acids by the colon. Gastroenterology 1980; 78: 1500-7.

43 Argenzio RA, Southworth M, Lowe JE, Stevens CE. Interrelationship of $\mathrm{Na}, \mathrm{CO}_{3} \mathrm{H}$ and volatile fatty acid transport by equine large intestine. Am J Physiol 1977; 2: E469-78.
44 Roediger WEW, Moore A. Effect of short-chain fatty acids on sodium absorption in isolated human colon perfused through the vascular bed. Am J Dig Dis 1981; 26: $100-6$.

4.5 Cook RM, Miller LD. Utilization of volatile fatty acids in ruminants. I. Removal of them from portal blood by the liver. J Dairy Sci 1965; 48: 1339-45.

46 Bergman EN, Wolff JE. Metabolism of volatile fatty acids by liver and portal-drained viscera in sheep. $A m J$ Physiol 1971; 221: 586-92.

47 Rémésy C, Demigné C. Chartier F. Origin and utilization of volatile fatty acids in the rat. Reprod Nutr Dévelop 1980; 20: 1339-49.

48 Jean-Blain C, Martin G. Effects of lactate, pyruvate, butyrate and ammonia on gluconeogenesis from propionate by isolated rabbit liver cells. Ann Rech Vétér 1980; 11: 427-36.

49 Aïkawa T, Matsutaka H, Takezawa K, Ishikawa E. Gluconeogenesis and aminoacids metabolism. IComparison of various precursors for hepatic gluconeogenesis in vivo. Biochim Biophys Acta 1972; 279: 234-44.

50) Thompson GE, Basset JM, Bell AW. The effects of feeding and acute cold exposure on the visceral release of volatile fatty acids, estimated hepatic uptake of propionate and release of glucose, and plasma insulin concentration in sheep. Br J Nutr 1978; 39: 219-26.

51 Wolff JE, Bergman EN, Williams HH. Net metabolism of plasma aminoacids by liver and portal-drained viscera of fed sheep. Am J Physiol 1972; 223: 438-46.

52 Wolff JE, Bergman EN. Metabolism and interconversions of five plasma aminoacids by tissues of the sheep. Am J Physiol 1972; 223: 447-54.

53 Beauville M, Raynaud P, Vernay MY. Concentration des acides gras volatils plasmatiques chez le lapin. Ann Rech Vétér 1974; 5: 407-11.

54 Elliot JM. Propionate metabolism and vitamin B 12. In: Ruckebusch Y, Thivend P, eds. Digestive physiology and metabolism in ruminants. Lancaster: MTP Press, 1980: 485-503. 